\title{
Milanesio, Natalia \\ Cuando los trabajadores salieron de compras: Nuevos consumidores, publicidad y cambio cultural durante el primer peronismo
}

Buenos Aires: Siglo XXI, 2014, 264 páginas $^{1}$.

$\mathrm{E}$ I trabajo de Natalia Milanesio se inscribe en el marco de estudios de consumo en la Argentina durante la etapa peronista, área que ha sido desatendida dentro de los abordajes que atañen al peronismo y la clase obrera. La figura central de este libro es el consumidor obrero, actor que es analizado a partir de la combinación de teorías de antropología del consumo, los estudios culturales y de género, metodologías de historia social, oral y cultural y de una variedad de fuentes que van desde los documentos estatales a los archivos de empresas y agencias de publicidad, hasta publicaciones de diarios y revistas, estadísticas, literatura y entrevistas orales.

Milanesio define el consumo como un fenómeno que incluye diferentes prácticas que exceden al acto económico y también establece complejas relaciones entre los sujetos sociales y, a su vez, entre los sujetos y los objetos. Dicho fenómeno representa así una experiencia sociocultural subjetiva, utilizada para validar o crear identidades, expresarse como individuo o grupo, diferenciarse, y crear formas de pertenencia y status social. Estudios de este tipo permiten ampliar los debates del cambio cultural, y posibilitan reflexiones sobre la identidad, los estereotipos, las relaciones de género y de clase, los imaginarios, entre otras temáticas. En este sentido, el eje de análisis está puesto en las transformaciones culturales y sociales que se llevaron adelante en el proceso de incorporación de los trabajadores al consumo masivo, proceso que la autora sitúa a mediados del siglo XX.

Este libro está compuesto por seis capítulos, una introducción y una conclusión. Si tenemos en cuenta las temáticas abordadas en los capítulos, es posible dividir la obra en dos partes. Por un lado, la primera parte se encarga de analizar tres cuestiones en particular: las transformaciones económicas, sociales y políticas que permitieron que los trabajadores incrementaran su poder adquisitivo, la definición del consumidor obrero, y los cambios que estos nuevos consumidores de menores ingresos suscitaron en la cultura comercial. Por su parte, la segunda parte se concentra en captar la importancia y el papel que tuvo el consumidor obrero en la transformación de los imaginarios de la época en torno a estereotipos de género y de clase, y el efecto que produjeron estas modificaciones en las identidades sociales.

El primer capítulo tiene como finalidad explicar al lector cuáles fueron las condiciones históricas que permitieron la expansión del mercado y la incorporación de

1. Una primera versión de este libro fue publicada en inglés, bajo el título Workers Go Shopping in Argentina: The Rise of Popular Consumer Culture (Albuquerque, University of New México Press, 2013). 
nuevos sectores sociales a éste. La autora argumenta que este gran cambio fue posible gracias a la implementación de políticas económicas nacionalistas, la industrialización orientada al mercado interno y el aumento del poder de consumo de los sectores trabajadores. Milanesio sostiene que el consumidor obrero fue el foco de interés del proyecto peronista, y que las mejoras en su calidad de vida, sobre todo en términos de capacidad de consumo, eran entendidas por el gobierno como un derecho. El peronismo defendía así un ideal de justicia social que entendía a la ciudadanía a partir no sólo de derechos políticos, sino también económicos y sociales. Con el objetivo de garantizar la prosperidad material y la "vida digna" de los trabajadores, el estado peronista implementó nuevas regulaciones que condujeron a asignar al estado un papel de mediador entre productores y consumidores. Es ilustrativa la intervención estatal, nacional y provincial, sin precedentes antes de este período en lo que respecta a la industria alimenticia. Entre las medidas aplicadas se incluían un mayor control sobre la producción, comercialización y publicidad de comestibles. Esto representó para la autora un cambio fundamental que implicó modificaciones en ámbitos culturales, sociales y económicos.

Luego, el capítulo siguiente centra su atención en las campañas publicitarias y su definición del recientemente incorporado sector social. Las agencias de publicidad transformaron a los trabajadores en un nuevo objeto de estudios de mercado, y apelaron a campañas educativas para instruirlos de manera adecuada en las prácticas de consumo. La expansión de la publicidad se manifestó no sólo con la integración de ese grupo social, sino que también se expresó en la ampliación de su radio de acción más allá del área geográfica de Buenos Aires. Asimismo, las campañas publicitarias de la década de los cuarenta y cincuenta se enfocaron especialmente en las mujeres de la clase trabajadora, que debían ser consumidoras bien informadas, defensoras del poder adquisitivo del salario. De esta manera, se asiste a la definición de los nuevos consumidores obreros a partir de una base de pertenencia de clase, geográfica y también de género.

El tercer capítulo se ocupa de exponer los cambios en la propaganda comercial, que incorporó durante el período estudiado nuevos discursos e imágenes que tienen como protagonista a los trabajadores. Con tal objetivo, la historiadora realiza un análisis de los elementos visuales, textuales y argumentativos de avisos publicitarios del período. Esto le permite afirmar que las transformaciones giraron en torno a la utilización de un lenguaje cotidiano, tipos retóricos de carácter inclusivo, el uso del humor, y el nuevo cliché publicitario femenino; la mujer sexy y bonita. Junto a estos cambios, también se produjo el aumento de la propaganda en la vía pública, que iba a la par de la expansión de la urbanización y que contribuyó a la difusión de una publicidad con nuevas características y que puso en práctica diferentes estrategias para atraer a los sectores populares, recientemente incorporados al consumo de mercado.

Por su parte, en el cuarto capítulo se hace referencia a los sentimientos de malestar e inquietudes que manifestaron las clases media y alta ante la eminente "invasión" de los trabajadores a espacios, prácticas y tipos de consumo que estos sectores habían monopolizado hasta la gestión peronista. Los sectores mejor posicionados veían como intrusos a estos nuevos consumidores, y el hecho de que tuviesen que "mezclarse" con ellos en salidas al cine, a restaurantes o de compras generó 
profundos temores vinculados con la pérdida de distinción, identificación y privilegios de clase. Milanesio advierte entonces que el consumo se convirtió en una "arena de conflicto", de puja para crear y mantener significados en torno a objetos y espacios.

El anteúltimo apartado se concentra en señalar la influencia que tuvieron los nuevos patrones de consumo en el amor, el matrimonio y las relaciones de género. El foco de atención está puesto en el accionar de publicaciones populares. La autora revela, a través del examen de la prensa, que es posible visibilizar de esta manera las tensiones producidas por las nuevas formas de consumo. Así mismo expone cómo este medio de comunicación promovió mensajes contrapuestos con respecto a las expectativas de realización personal y conyugal. En este sentido, la historiadora señala que la nueva cultura comercial de la clase obrera transformó y redefinió los roles y estereotipos de género, y los decisiones como contraer nupcias comenzaron a estar fuertemente relacionadas con el gasto, el ahorro y las expectativas sociales.

Por último, en el capítulo seis se lleva adelante un análisis en base a entrevistas de trabajadores que habían vivido el peronismo en sus años de juventud. El objetivo principal de la autora fue identificar en estos testimonios los patrones lingüísticos que los entrevistados utilizaron para crear sus identificaciones de clase. Milanesio sostiene que el consumo jugó un rol preponderante en los mecanismos de construcción subjetiva de los trabajadores y que, más allá de que el gobierno utilizó ciertos patrones culturales para validar su legitimidad como responsable del bienestar y del aumento del estándar de vida, estos sectores se constituyeron a sí mismos como agentes activos en el mercado de consumo. En su discurso, los mismos trabajadores enfatizaron sus esfuerzos individuales y colectivos como ciudadanos, y refutaron la visión del consumo como mera emulación social de la clase media. Para ellos, las aspiraciones de mejoría no estaban vinculadas con imitar el estilo de vida de las clases más acomodadas. Así, si bien los trabajadores detentaron una capacidad adquisitiva que permitió la obtención de nuevos objetos y prácticas antes desconocidas, el proceso de incorporación al mercado de consumo se desarrolló a partir de la reafirmación de valores culturales y hábitos colectivos tradicionales, que se apropiaron de estos nuevos patrones de manera selectiva. La autora afirma entonces que las distinciones de clase se mantuvieron y se reafirmaron.

El análisis realizado por Milanesio permite abordar un aspecto de la relación entre las clases obreras y el peronismo que todavía se encuentra poco estudiado por la historiografía argentina. Es menester destacar que su trabajo permite entender a la clase obrera desde una nueva perspectiva: como agente consumidor. La incorporación de este sector al mercado fue sin dudas un proceso que derivó en múltiples transformaciones, que la autora identifica y describe con claridad a lo largo de la obra. La combinación de técnicas, fuentes y metodologías le permitió abordar su objeto de estudio de manera interdisciplinaria, lo que convierte este libro en un gran aporte para seguir avanzando en el estudio del consumo como un componente fundamental para entender el desenvolvimiento de los sectores populares en ámbitos sociales y culturales más vastos. 